\title{
Seasonal and vertical variations of sinking particle fluxes in the West Caroline Basin
}

\author{
Hodaka KAWAHATA. ${ }^{\text {a,b }}$, Masumi YAMAMURO ${ }^{\text {a }}$, Hidekazu OHTA ${ }^{\text {c }}$ \\ ${ }^{a}$ Marine Geology Department of Geological Survey of Japan, 1-1-3 IIigashi Tsukuba, Ibaraki, 305, Japan \\ (E-mail: kawahata@gsj.go.jp) \\ ${ }^{b}$ Graduate School of Science, Tohoku University, Sendai, 980-77, Japan \\ ${ }^{\mathrm{c}}$ Kansai Environmental Engineering Center, Osaka, Japan
}

(Received 8/10/96, revised 2/07/97; accepted 16/07/97)

\begin{abstract}
A sediment trap experiment was carried out in the West Caroline Basin, located in the equatorial western Pacific between influences of the Asian monsoon and the open ocean. Annual mass flux at the shallow trap at Site 1 was $57.10 \mathrm{~g} \mathrm{~m}^{-2} \mathrm{yr}^{-1}$. Generally, the higher flux of organic matter was associated with higher activities of biogenic opal-producing and carbonate-producing plankton communities. In addition, as the organic matter content increases, the organic carbon/carbonate carbon ratio shows a tendency to increase. Carbonate-producing plankton was predominant during periods 1 and 3 (May to July and November to the beginning of December), which could be due to limited silica supply to the euphotic zone. On the other hand, surface sea water was more nutrient-rich during periods 2 and 4 (August to October and the end of December to April) at Site 1. These high total mass fluxes could be stimulated by wind.

The amount of biogenic components collected in the sediment traps and the accumulation in surface sediments at Site 1 could be compared with primary productivity values. Carbonate and biogenic opal fluxes were $99 \%$ and $90 \%$ less, respectively, in the surface sediments compared to those in the shallow sediment trap. This could be due to the reaction of sinking particles with undersaturated deep sea water just above the sea floor, rather than with the water column during sinking. About $20 \%$ of the organic matter was decomposed between the shallow and deep sediment traps and more than $98 \%$ between the deep sediment trap and final burial in the surface sediments. The relative amount of organic carbon preserved in surface sediments was about $0.10 \%$ of annual primary productivity. (C) Elsevier, Paris
\end{abstract}

\section{seasonality /vertical variations / sinking particle fluxes / Western Pacific / carbon cycle}

Résumé - Variations saisonnières et verticales des flux de particules dans le bassin des Carolines. Des pièges à sédiments ont été déployés dans le bassin des Carolines Occidentales (ouest du Pacifique équatorial), entre la zone d'influence de la mousson d'Asie et l'océan ouvert. À la station 1, le flux annuel au piège le moins profond est $57,10 \mathrm{~g} \mathrm{~m}^{-2} \mathrm{an}^{-1}$. Les flux élevés de matière organique sont généralement associés au développement des communautés planctoniques à test silicieux et carbonaté. De plus, le rapport carbone organique/carbone minéral tend à augmenter avec la teneur en matière organique. Le plancton carbonaté prédomine pendant les périodes 1 et 3 (de mai à juillet et de novembre au début décembre), probablement en raison de l'apport limité en silice dans la couche euphotique. L'eau superficielle est enrichie en éléments nutritifs pendant les périodes 2 et 4 (d'août à octobre et de la fin décembre à avril) à la station 1 . Ces flux élevés pourraient être favorisés par l'action du vent sur la surface océanique. La quantité de composés biogéniques collectés dans les pièges à sédiments et leur accumulation dans les sédiments superficiels du site 1 peuvent être comparées aux valeurs de productivité primaire. Les flux de carbonate et d'opale biogènes dans les sédiments de surface sont inférieurs, de $99 \%$ et $90 \%$ respectivement, aux flux dans le piège à sédiment le moins profond ; probablement par réaction des particules avec l'eau sous-saturée, à proximité du fond, plutôt que durant la chute des particules dans la colonne d'eau. Environ $20 \%$ de la matière organique est décomposée entre les deux niveaux de pièges à sédiments, et plus de $98 \%$ avant l'incorporation au sćdiment. Le carbone organique préservé dans les sédiments superficiels représente environ $0,10 \%$ de la productivité primaire annuelle. (C) Elsevier, Paris.

variation saisonnière / variation verticale / flux de particules / Pacifique occidental / cycle du carbone 


\section{INTRODUCTION}

Sediment trap experiments conducted in various ocean basins show that particle fluxes to the deep sea are related to surface primary productivity. However, our knowledge about primary productivity and export production in the different geochemical provinces is rather limited. Up to now, extensive studies on sinking particles have been carried out in the Panama Basin of the eastern Pacific [12, 14], the central Pacific [6, 13] and the eastern Atlantic [30] in order to understand the carbon cycle and its seasonal variation in high production regimes of the equatorial region. However, little is know about the vertical transport of carbon by sinking particles in the western equatorial Pacific, where the surface waters are warm and nutrients come from terrestrial runoff. The West Caroline Basin in this area provides a good opportunity to investigate sinking particles in relation to the carbon cycle. This area is mainly influenced by nutrient supply from coastal regions in the Philippine and Indonesian Islands, and is affected by the South-East Asian monsoon climate.

The transfer of carbon from the surface to the deep sea and/or sea floor is another important kcy to understanding the carbon cycle. The degradation of organic matter in the intermediate and deep waters and near the sea floor is associated with dissolved oxygen consumption and regeneration of nutrients and total dissolved $\mathrm{CO}_{2}$. Therefore, the change of downward flux of organic carbon and associated components and the shift in the Corganic/ Ccarbonate ratio through the water column and at the sediment-water interface need to be given consideration.

In order to understand the vertical flux of biological components and the relation between the formation of sinking particles and the meteorological factor, we collected sinking particles and surface sediments just below the trap mooring in the West Caroline Basin, which has warm surface waters and is affected by coastal currents.

\section{STUDY AREA}

The West Caroline Basin is located north of New Guinea (figure 1). The basin is surrounded by banks or islands in Melanesia, including the Palau Islands, to the west and north, and by the Eauripik rise to the east. The basin has a depth of $4000 \mathrm{~m}$ to $5000 \mathrm{~m}$ and hemipelagic sediments with a variety of carbonate contents are dominant in this area.

Three major currents are important in the West Caroline Basin (figure I): the North Equatorial Current and its branch and the Equatorial Counter Current. The North Equatorial Current is a west-bound flow and is observed between $25^{\circ} \mathrm{N}$ and $5^{\circ} \mathrm{N}$ near $170-180^{\circ} \mathrm{E}$ in February, while in August it descends no lower than $10^{\circ} \mathrm{N}$. On reaching the western end of the Pacific, the North Equatorial Current comes up against the continental barrier of the Philippines, where it divides into two branches. One branch turns to the south and feeds the east-bound Equatorial Counter Current [29].

\section{METHODS}

One mooring consisting of two SMD21-6000 (Nichiyugiken-kogyou Ltd., Tokyo) time-series sediment traps with a collection area of $0.5 \mathrm{~m}^{2}$ and 21-cup collectors on each was deployed at $2^{\circ} 59.8^{\prime} \mathrm{N}, 135^{\circ} 01.5^{\prime} \mathrm{E}$ (Site 1) in the West Caroline Basin (figure 1). The water depth at Site 1 was $4414 \mathrm{~m}$. The shallow and deep traps were deployed at depths of $1592 \mathrm{~m}$ and $3902 \mathrm{~m}$ (500 m above the sea floor) at Site 1 , respectively. The opening and closing of both the traps were synchronized with an error of less than two minutes and these periods are presented in table $I$.

Before deployment, sample bottles were filled with filtered sea water $(0.45 \mu \mathrm{m}$ filter $)$ with the addition of analytical grade formalin to make a $3 \%$ solution and buffered with sodium borate in order to retard bacterial activity in the trap material. Recovered samples were immediately refrigerated on board at approximately 2 to $4{ }^{\circ} \mathrm{C}$. Particle samples in $250 \mathrm{~mL}$ polyethylene sample bottles were transported to the Geological Survey of Japan under refrigeration at $2{ }^{\circ} \mathrm{C}$. Each trap sample was split into aliquots with a high precision splitter (McLaneWSD-10) after picking out all recognisable zooplankton "swimmers" by hand.

We used a desalted, homogenized $1 / 2$ split from each sample for the bulk analysis. Organic carbon was determined with a Yanako MT-5 CHN analyser after removing carbonate by acidification within ceramic sample boats using $\mathrm{HCl}$ vapour. Samples were weighed out into precombusted ceramic boats and $100 \mu \mathrm{L}$ ultra-pure water was pipetted into each sample boat [31]. The samples were reacted with $\mathrm{HCl}$ vapour to remove carbonate completely at room temperature for $24 \mathrm{~h}$ in a glass desiccator. which contained $500 \mathrm{~mL}$ of $12 \mathrm{~N} \mathrm{HCl}$. Then the samples were dried up to drive off $\mathrm{HCl}$ and water at $50{ }^{\circ} \mathrm{C}$ for at least $3 \mathrm{~h}$, before determining carbon with the $\mathrm{CHN}$ analyser. No filtration step was involved. Total carbon and nitrogen measurements were also made on dried and 


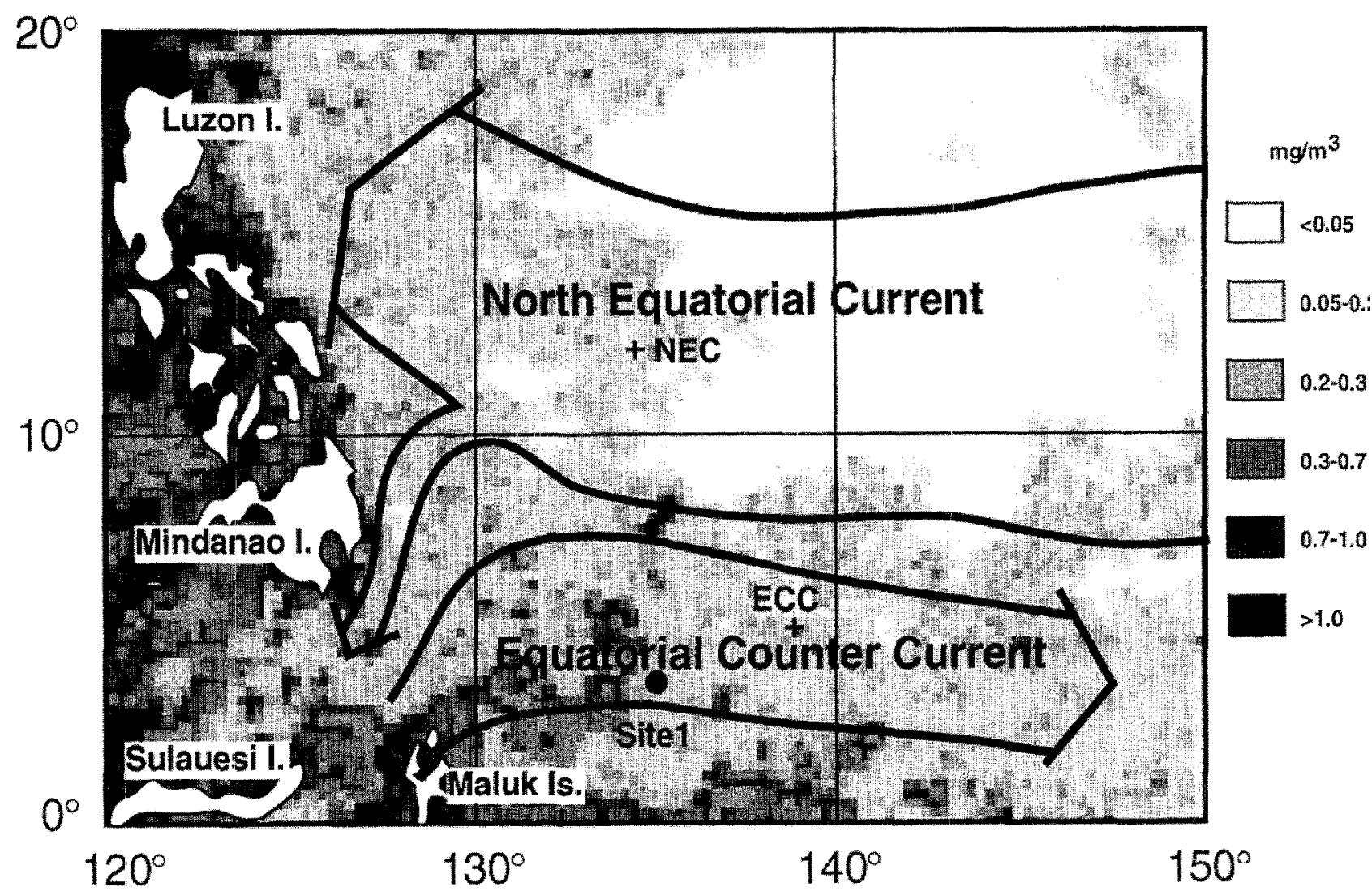

Figure 1. Locations of the mooring site and ocean surface current during spring of 1991 in the West Caroline Basin. Water depth at Site 1 was $4414 \mathrm{~m}$ and sediment traps were deployed at 1592 and $3902 \mathrm{~m} \mathrm{(500} \mathrm{m} \mathrm{above} \mathrm{the} \mathrm{sea} \mathrm{floor),} \mathrm{respectively.} \mathrm{Global} \mathrm{phytoplankton} \mathrm{pigment} \mathrm{con-}$ centrations $\left(\mathrm{mg} \mathrm{m}^{-3}\right.$ ) were revealed by three-month composites for October-December, 1979. The observations made from the Coastal Zone Color Scanner (CZCS), a radiometer that operated on NASA' Nimbus-7 satellite. NEC and ECC sites are located at $12^{\circ} 01.00^{\prime} \mathrm{N}, 134^{\circ} 17.16^{\prime}$ $\mathrm{E}$ and $5^{\circ} 00.60^{\prime} \mathrm{N}, 138^{\circ} 49.81^{\prime} \mathrm{E}$, respectively (Kempe and Knaack, 1996).

ground bulk sediment samples with the CHN analyser. Carbonate content was calculated from the difference between total carbon and organic carbon contents. The relative standard deviations of carbonate, organic carbon and total nitrogen are $1 \%, 7 \%$ and $8 \%$ in the case of duplicate analysis for carbonate, organic carbon and total nitrogen contents of $90 \mathrm{wt} \%, 0.2 \mathrm{wt} . \%$ and $0.02 \mathrm{wt} . \%$, respectively.

Biogenic silica, or opal content, was analysed using the sodium-carbonate leaching method modified from Mortlock and Froelich [22]. Approximately 2 to $5 \mathrm{mg}$ of an aliquot sample was weighed into a $20 \mathrm{~mL}$ polypropylene vial. $1 \mathrm{~mL} 1 \mathrm{~N} \mathrm{HCl}$ solution was added to the vial to dissolve out carbonate, and then dried up at $40-50{ }^{\circ} \mathrm{C}$. Then $1 \mathrm{~mL} 2 \% \mathrm{H}_{2} \mathrm{O}_{2}$ solution was added to remove organics, and again dried up at $40-50{ }^{\circ} \mathrm{C}$. Exactly $10 \mathrm{~mL} 7 \% \mathrm{Na}_{2} \mathrm{CO}_{3}$ solution was added with a repipit to the vial, which was then capped and mixed well, sonified and placed in a constant-temperature water bath pre-heated to $85^{\circ} \mathrm{C}$. The sample was shaken vigorously every hour. After $6 \mathrm{~h}$, the vial was removed from the bath. Residues of selected samples were examined under an optical microscope to verify complete dissolution of the siliceous micro-organisms. Several samples that gave unusual values were analysed three times, yielding a precision of $\pm 3 \%$ of the measured values.

The contribution of lithogenic matter was calculated as follows: Lithogenic $=$ Total - Carbonate - Opal $-1.8 \times$ Corganic (= organic matter). Sediment aliquots for AMS ${ }^{14} \mathrm{C}$ dating were disaggregated, wet-sieved at $63 \mu \mathrm{m}$ and picked for Globorotalia tumida which was analysed for the dating. G. tumida, a deep-dwelling planktonic foraminifer, was used because it is the only species consis- 
Table I. Sampling dates, flux rates, percentages and various ratios ( $\mathrm{C} / \mathrm{N}$, opal/Carbonate and Corg/Ccarbonate) of material collected at Site 1 .

\begin{tabular}{|c|c|c|c|c|c|c|c|c|c|c|c|c|c|c|}
\hline \multirow{2}{*}{$\begin{array}{l}\text { Sample } \\
\text { number }\end{array}$} & Trap cup & \multirow{2}{*}{$\begin{array}{c}\text { Duration } \\
\text { days }\end{array}$} & \multicolumn{6}{|c|}{ Fluxes in $\mathrm{mg} \mathrm{m}^{-2} \mathrm{day}^{-1}$} & \multicolumn{3}{|c|}{$\%$ of Total } & \multirow{2}{*}{\multicolumn{2}{|c|}{$\begin{array}{c}\text { C/N Opal/ } \\
\text { atom Carbonate } \\
\text { wt.wt. }\end{array}$}} & \multirow{2}{*}{$\begin{array}{c}\text { Corg/ } \\
\text { Cearborate } \\
\text { atom }\end{array}$} \\
\hline & open - close & & Total & Carbonate & $\begin{array}{l}\text { Organic } \\
\text { matter }\end{array}$ & $\begin{array}{c}\text { Biogenic } \\
\text { opal }\end{array}$ & Lithogenics & Carbonate & $\begin{array}{l}\text { Organic } \\
\text { matter }\end{array}$ & $\begin{array}{c}\text { Biogenic } \\
\text { opal }\end{array}$ & Lithogenics & & & \\
\hline \multicolumn{15}{|c|}{ Shallow trap } \\
\hline 1 & 4-Jun-91 - 15-Jun-91 & 12 & 139.0 & 55.0 & 15.3 & 32.1 & 36.6 & 39.5 & 11.0 & 23.1 & 26.3 & 8.1 & 0.58 & 1.29 \\
\hline 2 & 16-Jun-91 - 30-Jun-91 & 15 & 151.2 & 87.1 & 10.8 & 31.8 & 21.6 & 57.6 & 7.1 & 21.0 & 14.3 & 8.2 & 0.37 & 0.57 \\
\hline 3 & 1-Jul-91 - 15-Jul-91 & 15 & 135.0 & 70.2 & 15.8 & 30.4 & 18.5 & 52.0 & 11.7 & 22.5 & 13.7 & 7.5 & 0.43 & 1.04 \\
\hline 4 & 16-Jul-91 - 31-Jul-91 & 16 & 116.1 & 57.9 & 11.0 & 22.4 & 24.7 & 49.9 & 9.5 & 19.3 & 21.3 & 8.0 & 0.39 & 0.88 \\
\hline 5 & 1-Aug-91 - 15-Aug-91 & 15 & 127.8 & 79.2 & 10.9 & 22.9 & 14,8 & 62.0 & 8.5 & 17.9 & 11.6 & 7.2 & 0.29 & 0.63 \\
\hline 6 & 16-Aug-91 - 31-Aug-91 & 16 & 218.7 & 127.8 & 21.5 & 53.9 & 15.6 & 58.4 & 9.8 & 24.6 & 7.1 & 7.6 & 0.42 & 0.77 \\
\hline 7 & $1-$ Sep-91-15-Sep-91 & 15 & 180.3 & 84.0 & 20.1 & 38.9 & 37.4 & 46.6 & 11.1 & 21.6 & 20.7 & 7.4 & 0.46 & 1.10 \\
\hline 8 & 16-Sep-91-30-Sep-91 & 15 & 294.2 & 119.4 & 36.0 & 87.1 & 51.7 & 40.6 & 12.2 & 29.6 & 17.6 & 8.2 & 0.73 & 1.39 \\
\hline 9 & 1-0ct-91 - 15-0ct-91 & 15 & 198.6 & 80.1 & 24.4 & 43.2 & 50.8 & 40.3 & 12.3 & 21.8 & 25.6 & 7.2 & 0.54 & 1.40 \\
\hline 10 & 16-Oct-91-31-Oct-91 & 16 & 138.1 & 49.4 & 14.4 & 20.5 & 53.8 & 35.8 & 10.4 & 14.8 & 39.0 & 79 & 0.41 & 1.34 \\
\hline 11 & 1-Nov-91 - 15-Nov-91 & 15 & 132.1 & 58.2 & 11.4 & 22.4 & 40.1 & 44.1 & 8.6 & 16.9 & 30.4 & 6.4 & 0.38 & 0.90 \\
\hline 12 & 16-Nov-91 - 30-Nov-91 & 15 & 155.0 & 74.7 & 15.0 & 35.5 & 29.8 & 48.2 & 9.7 & 22.9 & 19.2 & 7.8 & 0.47 & 0.92 \\
\hline 13 & 1-Dec-91 - 15-Dec-91 & 15 & 137.8 & 64,4 & 12.6 & 30.0 & 30.9 & 46.7 & 9.1 & 21.7 & 22.4 & 7.3 & 0.47 & 0.90 \\
\hline 14 & 16-Dec-91-31-Dec-91 & 16 & 252.1 & 120.3 & 28.8 & 56.8 & 46.2 & 47.7 & 11.4 & 22.5 & 18.3 & 8.1 & 0.47 & 1.10 \\
\hline 15 & 1-Jan- $-92-15-J a n-92$ & 15 & 217.5 & 94.6 & 20.6 & 48.5 & 53.8 & 43.5 & 9.4 & 22.3 & 24.7 & 7.0 & 0.51 & 1.00 \\
\hline 16 & 16-Jan-92-31-Jan-92 & 16 & 256.1 & 83.8 & 26.1 & 95.3 & 51.0 & 32.7 & 10.2 & 37.2 & 19.9 & 7.8 & 1.14 & 1.43 \\
\hline 17 & 1-Feb-92-15-Feb-92 & 15 & 124.5 & 63.7 & 11.5 & 25.0 & 24.2 & 51.2 & 9.2 & 20.1 & 19.5 & 7.1 & 0.39 & 0.83 \\
\hline 18 & 16-Feh-92-15-Apr-92 & 60 & 960 & 30.9 & 11.6 & 39.4 & 14.1 & 32.1 & 12.1 & 41.1 & 14.7 & 8.2 & 1.28 & 1.73 \\
\hline \multicolumn{15}{|l|}{ Deep trap } \\
\hline 1 & 4-Jun-91 - 15-Jun-91 & 12 & 1050 & 41.8 & 10.0 & 23.4 & 29.8 & 39.8 & 9.5 & 22.3 & 28.4 & 7.6 & 0.56 & 1.10 \\
\hline 2 & 16-Jun-91 - 30-Jun-91 & 15 & 97.9 & 50.8 & 7.5 & 22.0 & 17.7 & 51.9 & 7.6 & 22.5 & 18.0 & 7.6 & 0.43 & 0.68 \\
\hline 3 & |-Jul-91 - 15-Jul-91 & 15 & 116.1 & 69.8 & 8.5 & 27.7 & 10.2 & 60.1 & 7.3 & 23.9 & 8.8 & 7.0 & 0.40 & 0.56 \\
\hline 4 & 16-Ju1-91 - 31-Jul-91 & 16 & 121.0 & 56.4 & 9.7 & 25.3 & 29.5 & 46.6 & 8.0 & 20.9 & 24.4 & 7.6 & 0.45 & 0.79 \\
\hline 5 & 1-Aug-91 - 15-Aug-91 & 15 & 140.9 & 71.7 & 10.6 & 24.3 & 34.4 & 50.9 & 7.5 & 17.2 & 24.4 & 7.1 & 0.34 & 0.68 \\
\hline 6 & 16-Aug-91 - 31-Aug-91 & 16 & 156.1 & 88.6 & 8.9 & 22.7 & 35.9 & 56.8 & 5.7 & 14.6 & 23.0 & 8.0 & 0.26 & 0.46 \\
\hline 7 & 1-Sep-91 - 15-Sep-91 & 15 & 229.7 & 86.6 & 27.9 & 63.3 & 52.0 & 37.7 & 12.1 & 27.5 & 22.6 & 8.0 & 0.73 & 1.48 \\
\hline 8 & 16-Sep-91 - 30-Sep-91 & 15 & 200.6 & 103.7 & 13.6 & 38.6 & 44.7 & 51.7 & 6.8 & 19.2 & 22.3 & 8.1 & 0.37 & 0.60 \\
\hline 9 & 1-Oct-91 - 15-Oct-91 & 15 & 298.1 & 124.0 & 31.0 & 90.0 & 53.1 & 41.6 & 10.4 & 30.2 & 17.8 & 6.5 & 0.73 & 1.15 \\
\hline 10 & $16-0 c t-91-31-0 c t-91$ & 16 & 178.8 & 50.8 & 14.1 & 30.4 & 83.5 & 28.4 & 7.9 & 17.0 & 46.7 & 8.0 & 0.60 & 1.27 \\
\hline$! 1$ & [-Nov-91 - 15-Nov-9] & 15 & 149.2 & 52.5 & 11.1 & 24.9 & 60.6 & 35.2 & 7.5 & 16.7 & 40.6 & 6.8 & 0.47 & 0.98 \\
\hline 12 & 16-Nov-9] - 30-Nov-91 & 15 & 142.8 & 70.9 & 8.5 & 25.1 & 38.3 & 49.6 & 6.0 & 17.6 & 26.8 & 7.6 & 0.35 & 0.55 \\
\hline 13 & [-Dec-91 - 15-Dec-9] & 15 & 131.1 & 56.4 & 10.9 & 29.7 & 34.1 & 43.0 & 8.3 & 22.7 & 26.0 & 6.7 & 0.53 & 0.89 \\
\hline 14 & 16-Dec-91 - 31-Dec-91 & 16 & 231.2 & 80.8 & 31.6 & 36.4 & 82.4 & 35.0 & 13.6 & 15.8 & 35.6 & 8.1 & 0.45 & 1.80 \\
\hline 15 & 1-Jan-92 - 15-Jan-92 & 15 & 174.8 & 83.7 & 15.8 & 44.7 & 30.6 & 47.9 & 9.0 & 25.6 & 17.5 & 7.3 & 0.53 & 0.87 \\
\hline 16 & 16-Jan-92 - 31-Jan-92 & 16 & 179.6 & 75.8 & $\begin{array}{r}1412 \\
.6\end{array}$ & 59.3 & 30.0 & 42.2 & 8.1 & 33.0 & 16.7 & 7.7 & 0.78 & 0.89 \\
\hline 17 & 1-Feb-92-15-Feb-92 & 15 & 316.0 & 88.0 & 31.5 & 148.8 & 47.7 & 27.8 & 10.0 & 47.1 & 15.1 & 7.0 & 1.69 & 1.65 \\
\hline 18 & 16-Feb-92-15-Apr-92 & 60 & 69.0 & 22.5 & 7.3 & 29.0 & 10.3 & 32.6 & 10.5 & 42.0 & 14.9 & 7.8 & 1.29 & 1.49 \\
\hline
\end{tabular}

tently abundant enough for the analysis. The analyses were performed on four levels in the surface sediments in the Nuclear Sciences, New Zealand.

\section{RESULTS}

Records from two water depths at Site 1 are listed in table I. Annual mass fluxes were 57.10 and $53.83 \mathrm{~g} \mathrm{~m}^{-2} \mathrm{yr}^{-1}$ at
$1592 \mathrm{~m}$ and $3902 \mathrm{~m}$ water depth, respectively (table II). Calcium carbonate $\left(\mathrm{CaCO}_{3}\right)$ was generally the major component of settling particles, followed by biogenic opal (silica). The amount of lithogenic matter was about twice that of particulate organic matter (POM). The average concentrations of $\mathrm{CaCO}_{3}, \mathrm{POM}$, opal, and lithogenic matter were $43.7 \%, 10.6 \%, 25.7 \%$, and $20.0 \%$ at the shallow trap and $41.2 \%, 9.1 \%, 26.2 \%$, and $23.5 \%$ at the deep trap, respectively. 
Sinking particle fluxes showed seasonal variations. The period of sample collection can be divided into four periods based upon the total mass fluxes and the compositions: period 1 (May to July); period 2 (August to October); period 3 (November to the beginning of December); and period 4 (the end of December to April) (figures 2 and 3). Although there is a lack of data for May, period 1 is assumed to start in May because similar pictures were obtained on sea-surface current and temperature in May to July in 1991 based upon the data set provided by the Meteorological Institute of Japan. High total mass flux associated with a higher content of POM characterised periods 2 and 4 , while low total mass fluxes were observed during periods 1 and 3 .

The sinking particle flux pattern at the shallow depth was generally imprinted at the deep level with time-lags. For example, by comparing the "peak-valley" succession of fluxes within period 2, the penetration of total flux from $1592 \mathrm{~m}$ to $3902 \mathrm{~m}$ was shifted for one sampling period (about two weeks), which gives a sinking speed of about $160 \mathrm{~m} \mathrm{day}^{-1}$, a value consistent with previous results [10]. Furthermore, total mass flux determined at the shallow trap was higher than that measured at the deep trap. These findings indicate that vertical transport was a major process in the West Caroline Basin. It is compatible with no occurrence of turbidites in the sedimentary core retrieved from Site 1 [18].

Carbonate was the major constituent of the mass flux and consisted of coccolithophores/coccoliths, planktonic for- aminiferal tests, and pteropod shells. In this paper, as presented in table $I$, we did not distinguish carbonates by origin. The annual carbonate flux observed at the shallow trap at Site 1 was about $13 \%$ higher than that observed at the deep trap. Organic matter fluxes were higher during periods 2 and 3 than during the other periods. $\mathrm{C} / \mathrm{N}$ atomic ratios of sinking particles were on average 7.3 , showing no definite seasonal variations (table II).

The annual fluxes of biogenic opal at Site 1 were about $14 \mathrm{~g} \mathrm{~m}^{-2} \mathrm{yr}^{-1}$ at both depths. High opal fluxes were generally accompanied by peaks of total mass fluxes. Opal fluxes were sometimes higher at the deep trap than at the shallow trap in September to October and in February when carbonate and organic carbon fluxes showed similar patterns. It takes more time for sinking particles to reach the deeper trap through the water column. Therefore, the fluxes at the deep trap could reflect surface ocean conditions in a larger area due to lateral advection.

The mass fluxes of carbonate and biogenic opal are plotted against organic matter flux in figure $4 a$. Data from the shallow sediment trap only are presented here in order to avoid complications from degradation or from resuspension in the bottom water. These data indicate that biogenic opal and organic matter fluxes are strongly correlated $(r=0.83)$ as are carbonate and organic matter, but to a lesser extent $(\mathrm{r}=0.75)$ (figure $4 a$ ). Samples with higher biogenic opal fluxes were associated with higher organic matter and carbonate fluxes and belonged to the field with a Corganic/Ccarbonate ratio $>1$ (figure $4 b$ ).

Table II. Seasonal variation of MARs of components to the deep Caroline Basin and their ratios.

\begin{tabular}{|c|c|c|c|c|c|c|c|c|c|c|c|c|c|c|c|}
\hline \multirow[t]{2}{*}{ Period } & \multirow[t]{2}{*}{ Trap } & \multirow[t]{2}{*}{$\begin{array}{l}\text { Total } \\
\text { MAR } \\
\left(\mathrm{g} / \mathrm{m}^{2}\right)\end{array}$} & \multicolumn{2}{|c|}{$\begin{array}{l}\text { Carbonate } \\
\text { MAR }\end{array}$} & \multicolumn{2}{|c|}{$\begin{array}{c}\text { Organic } \\
\text { matter } \\
\text { MAR }\end{array}$} & \multicolumn{2}{|c|}{$\begin{array}{c}\text { Total nitrogen } \\
\text { MAR }\end{array}$} & \multicolumn{2}{|c|}{$\begin{array}{c}\text { Biogenic Opal } \\
\text { MAR }\end{array}$} & \multicolumn{2}{|c|}{$\begin{array}{l}\text { Lithogenic } \\
\text { MAR }\end{array}$} & \multirow[t]{2}{*}{$\begin{array}{r}\mathrm{C} / \mathrm{N} \\
\text { atom }\end{array}$} & \multirow[t]{2}{*}{$\begin{array}{l}\text { Corg/ } \\
\text { Ccarb } \\
\text { atom }\end{array}$} & \multirow[t]{2}{*}{$\begin{array}{c}\text { Opal/ } \\
\text { Carbonate } \\
\text { wt.wt. }\end{array}$} \\
\hline & & & $\left(\mathrm{g} / \mathrm{m}^{2}\right)$ & $(\%)$ & $\left(\mathrm{g} / \mathrm{m}^{2}\right)$ & $(\%)$ & $\left(\mathrm{g} / \mathrm{m}^{2}\right)$ & $(\%)$ & $\left(\mathbf{g} / \mathbf{m}^{2}\right)$ & $(\%)$ & $\left(\mathrm{g} / \mathrm{m}^{2}\right)$ & $(\%)$ & & & \\
\hline \multicolumn{16}{|l|}{ Site 1} \\
\hline \multirow[t]{2}{*}{ Spring } & Shallow & 12.55 & 5.81 & 46.3 & 1.28 & 10.2 & 0.10 & 0.8 & 2.77 & 22.1 & 2.68 & 21.4 & 7.57 & 1.02 & 0.48 \\
\hline & deep & 9.98 & 4.63 & 46.4 & 0.86 & 8.6 & 0.07 & 0.7 & 2.23 & 22.3 & 2.26 & 22.7 & 7.11 & 0.85 & 0.48 \\
\hline \multirow[t]{2}{*}{ Summer } & Shallow & 17.72 & 8.28 & 46.7 & 1.94 & 11.0 & 0.16 & 0.9 & 4.07 & 23.0 & 3.43 & 19.4 & 7.25 & 1.09 & 0.49 \\
\hline & deep & 18.40 & 8.02 & 43.6 & 1.61 & 8.8 & 0.14 & 0.8 & 4.09 & 22.2 & 4.67 & 25.4 & 7.05 & 0.93 & 0.51 \\
\hline \multirow[t]{2}{*}{ 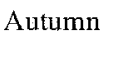 } & Shallow & 6.37 & 2.96 & 16.4 & 0.58 & 9.2 & 0.05 & 0.8 & 1.32 & 20.7 & 1.51 & 23.7 & 6.77 & 0.91 & 0.44 \\
\hline & deep & 6.35 & 2.70 & 42.5 & 0.46 & 7.2 & 0.04 & 0.7 & 1.20 & 18.8 & 2.00 & 31.5 & 6.60 & 0.79 & 0.44 \\
\hline \multirow[t]{2}{*}{ Winter } & Shallow & 20.46 & 7.95 & 38.9 & 2.23 & 10.9 & 0.18 & 0.9 & 6.49 & 31.7 & 3.78 & 18.5 & 7.41 & 1.30 & 0.82 \\
\hline & deep & 19.11 & 6.77 & 35.4 & 1.99 & 10.4 & 0.17 & 0.9 & 6.61 & 34.6 & 3.74 & 19.6 & 7.17 & 1.36 & 0.98 \\
\hline \multirow{2}{*}{$\begin{array}{l}\text { Total } \\
\text { annual }\end{array}$} & Shallow & 57.10 & 25.00 & 43.7 & 6.04 & 10.6 & 0.51 & 0.9 & 14.65 & 25.7 & 11.41 & 20.0 & 7.32 & 1.12 & 0.59 \\
\hline & deep & 53.83 & 22.12 & 41.2 & 4.92 & 9.1 & 0.43 & 0.8 & 14.12 & 26.2 & 12.67 & 23.5 & 7.06 & 1.03 & 0.64 \\
\hline
\end{tabular}

Spring: May-July ; Summer: August-October; Autumn: November-15 December; Winter: 16 December-April. 

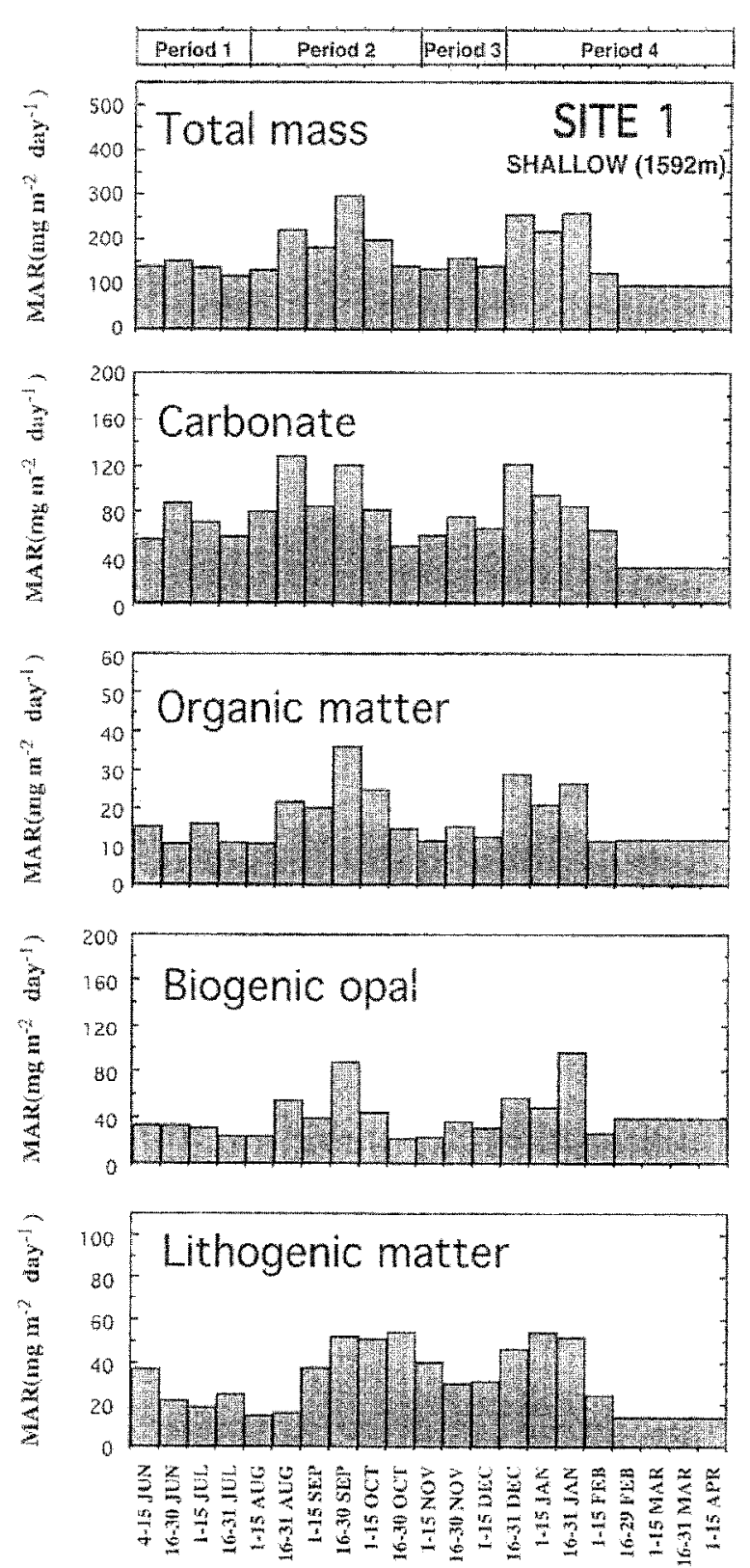

Tigure 2. Fluxes of total mass, carbonate, organic matter, biogenic opal, and lithogenic matter from June 1991 to March 1992 at the shallow trap of Site 1.

At the shallow rap, the annual lithogenic flux at Site 1 was $11.4 \mathrm{~g} \mathrm{~m}^{-2} \mathrm{yr}^{-1}$. The lithogenic matter was largely composed of clay minerals. Volcanic ash was only a minor contributor. High lithogenic fluxes were accompanied with high total mass fluxes as was observed for opal fluxes (figures 2 and 3).
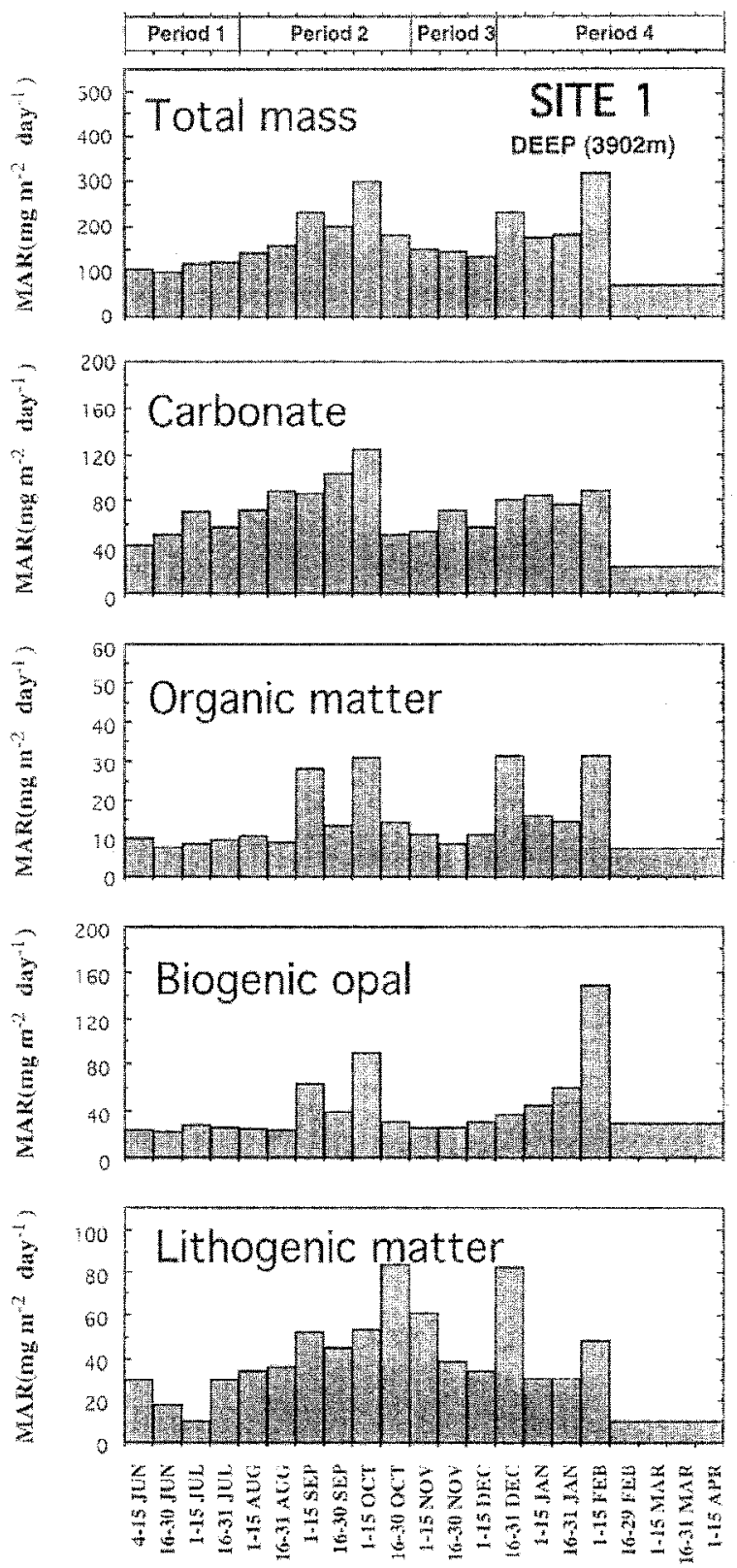

Figure 3. Fluxes of total mass, carbonate, organic matter, biogenic opal, and lithogenic matter from June 199/ to March 1992 at the deep trap of Site 1.

Radiocarbon ages obtained on Globorotalia tumida in the surface sediments at Site 1 were $1041 \pm 62,6361 \pm 73$, $7660 \pm 81$ and $11588 \pm 89$ yr.B.P. at the subbottom depth of $0-1 \mathrm{~cm}, 7-9 \mathrm{~cm}, 15-17 \mathrm{~cm}$ and $23-25 \mathrm{~cm}$, respectively. These results give a linear sedimentation rate of $2.26 \mathrm{~cm} \mathrm{kyr}^{-1}$ in the surface sediments. Based upon smear 

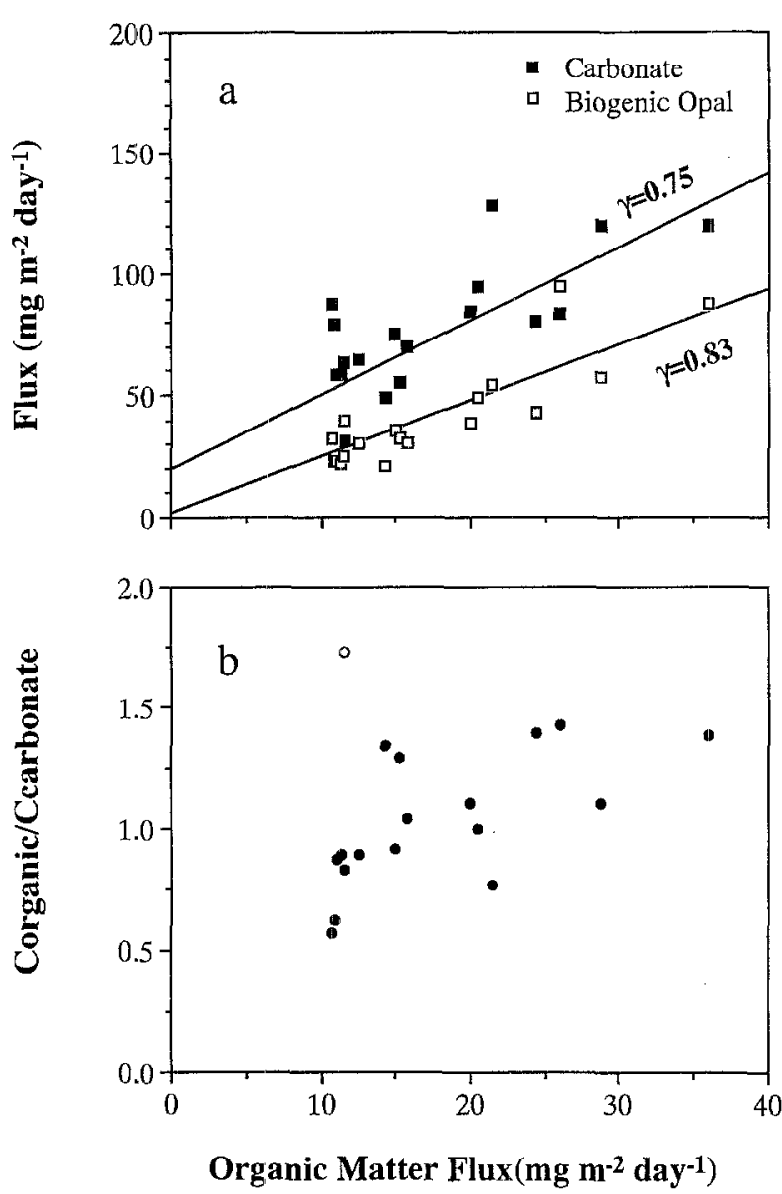

Figure 4. Biogenic opal ( ) and carbonate fluxes ( $\boldsymbol{\square}$ ) (a) and carbon rain ratios $(\mathbf{O}, \mathrm{O})$ (b) versus organic matter flux from the shallow trap at Site 1. Open circle represents a sample taken for two months (from February 16 to April 15) while solid circles represent samples collected for a half month.

slide examination and soft X-ray analysis, neither gradedbedding nor cross-lamination was observed in a $35 \mathrm{~cm}$ thick layer of surface sediments. One to three millimetrethick surface sediments were served for chemical analysis. The contents of carbonate carbon, organic carbon, total nitrogen, biogenic opal and lithogenic matter were $0.16,0.80,0.13,15.72$ and 81.51 wt. $\%$, respectively. Their mass accumulation rates (MARs) were 0.0155 , $0.0777,0.0119,1.53$ and $7.92 \mathrm{gm}^{-2} \mathrm{yr}^{-1}$, respectively. MARs ( $\mathrm{mg} \mathrm{cm}^{-2} \mathrm{kyr}^{-1}$ ) were calculated by multiplying the linear sedimentation rate $\left(\mathrm{cm} \mathrm{kyr}^{-1}\right)$ by dry bulk density $\left(0.43 \mathrm{~g} \mathrm{~cm}^{-3}\right)$ to give the bulk MAR $\left(\mathrm{g} \mathrm{cm}^{-2} \mathrm{kyr}^{-1}\right)$ and then by the content of each component to give its mass accumulation rate.

\section{DISCUSSION}

\subsection{General characteristics of particle fluxes in the West Caroline Basin}

Annual mass flux at the shallow trap at Site 1 is $57.10 \mathrm{~g}$ $\mathrm{m}^{-2} \mathrm{yr}^{-1}$. Sediment trap expcriments in the eastern part of the West Caroline Basin $\left(5^{\circ} \mathrm{N}, 139^{\circ} \mathrm{E}\right)$ and the Philippine Basin $\left(12^{\circ} \mathrm{N}, 134^{\circ} \mathrm{E}\right)$ gave annual fluxes of $6.57 \mathrm{~g}$ $\mathrm{m}^{-2} \mathrm{yr}^{-1}$ and $1.73 \mathrm{~g} \mathrm{~m}^{-2} \mathrm{yr}^{-1}$ at water depths of $1130 \mathrm{~m}$ and $1200 \mathrm{~m}$, respectively [19]. Such north-eastward decreasing fluxes reflect the steep gradients of primary productivity. Comparison of annual fluxes in the equatorial region of the Pacific Ocean shows that the annual fluxes in the West Caroline Basin were less than that $(124.7 \mathrm{~g}$ $\mathrm{m}^{-2} \mathrm{yr}^{-1}$ ) observed at a water depth of $1268 \mathrm{~m}$ in the Panama Basin of the eastern equatorial Pacific $\left(5^{\circ} \mathrm{N}, 86^{\circ} \mathrm{W}\right)$ [12] and comparable to those $\left(21.77 \mathrm{~g} \mathrm{~m}^{-2} \mathrm{yr}^{-1}\right.$ at a water depth of $3495 \mathrm{~m}$ in 1983 and $41.74 \mathrm{~g} \mathrm{~m}^{-2} \mathrm{yr}^{-1}$ at a water depth of $2908 \mathrm{~m}$ in 1984 at $1^{\circ} \mathrm{N}, 139^{\circ} \mathrm{W} ; 22.3$ to $34.8 \mathrm{~g}$ $\mathrm{m}^{-2} \mathrm{yr}^{-1}$ at water depths between 2200 and $3618 \mathrm{~m}$ at $5^{\circ} \mathrm{S}$ to $5^{\circ} \mathrm{N}, 140^{\circ} \mathrm{W}$ ) observed in the middle part of the equatorial Pacific $[6,13]$. This is also ascribed to the general trend of primary productivity gradients, which decrease gradually from east to west between $80^{\circ} \mathrm{W}$ and $170^{\circ} \mathrm{E}$ and from west to east between $130^{\circ} \mathrm{E}$ and $150^{\circ} \mathrm{E}$ [20].

Positive correlation between the mass flux and the organic matter indicated that sedimentation of particles was linked to biological processes in the surface sea water. Whereas the important autotrophs found in the samples during periods 1 and 3 were coccolithophorids, which might have provided mucus for the agglutination of mineral particles and biogenic hardparts, diatoms were dominant during periods 2 and 4 . Coccolithophorids are well known to form aggregates with nonbiogenic particles and accelerate the sinking speed of small particles. Besides, the incorporation of lithogenic particles into organic aggregates forms high-density particles with faster sinking speed, which prevents the degradation of organic matter through the water column [7, 15]. As mentioned before, the sinking speeds of total mass could be evaluated by examining flux maxima of $1592 \mathrm{~m}$ and $3902 \mathrm{~m}$ data. In September and October, one sampling lag time was observed between the two depths, which gave a mean sinking speed of around $160 \mathrm{~m}$ day $^{-1}$ (figures 2 and 3 ). This is compatible with the sinking speeds of diatoms of $175 \mathrm{~m} \mathrm{day}^{-1}$ [28].

Generally, higher fluxes of organic matter are associated with higher activities of biogenic opal- and carbonateproducing plankton communities (figure $4 a$ ). As the 
organic matter content increases, the organic carbon/carbonate carbon ratio shows a tendency to increase (figure $4 b$ ). Carbonate-producing plankton is predominant during periods 1 and 3 . Figure 5 shows water temperature, fluorescence (an indicator for chlorophyll $a$ ), and nutrient concentration profiles obtained during period 1 in 1991 and 1992 at Site 1 and nearby. The results indicate that chlorophyll $a$, a representative index of phytoplankton, has a large peak at a depth of $74 \mathrm{~m}$ and is completely depleted below $200 \mathrm{~m}$.

Phosphate and silica profiles with detailed sampling of the upper $300 \mathrm{~m}$ were depleted in surface waters with its more stratified surface waters during period 1 . These concentrations changed near the thermocline, present around $170 \mathrm{~m}$ depth, where the silica/phosphate $\left(\mathrm{SiO}_{2} / \mathrm{PO}_{4}\right)$ atomic ratios increased rapidly from 2 to 19. High primary productivity in association with predominance of diatoms characterises the northern part of the western Pacific, whose surface water shows silica/phosphate atomic ratios of more than 15 . It implies a high input of silica into the surface water for sustaining siliceous plankton communities. These lines of evidence suggest that limited silica supply to the euphotic zone at site 1 could be responsible for the inhibition of growth of siliceous plankton, and thus help in the development of calcareous plankton.

\subsection{Comparison of mass accumulation rates between sediment traps and surface sediments}

The deep trap was deployed at about $3902 \mathrm{~m}$ water depth, which is about $500 \mathrm{~m}$ above the sea floor at Site 1 . If we
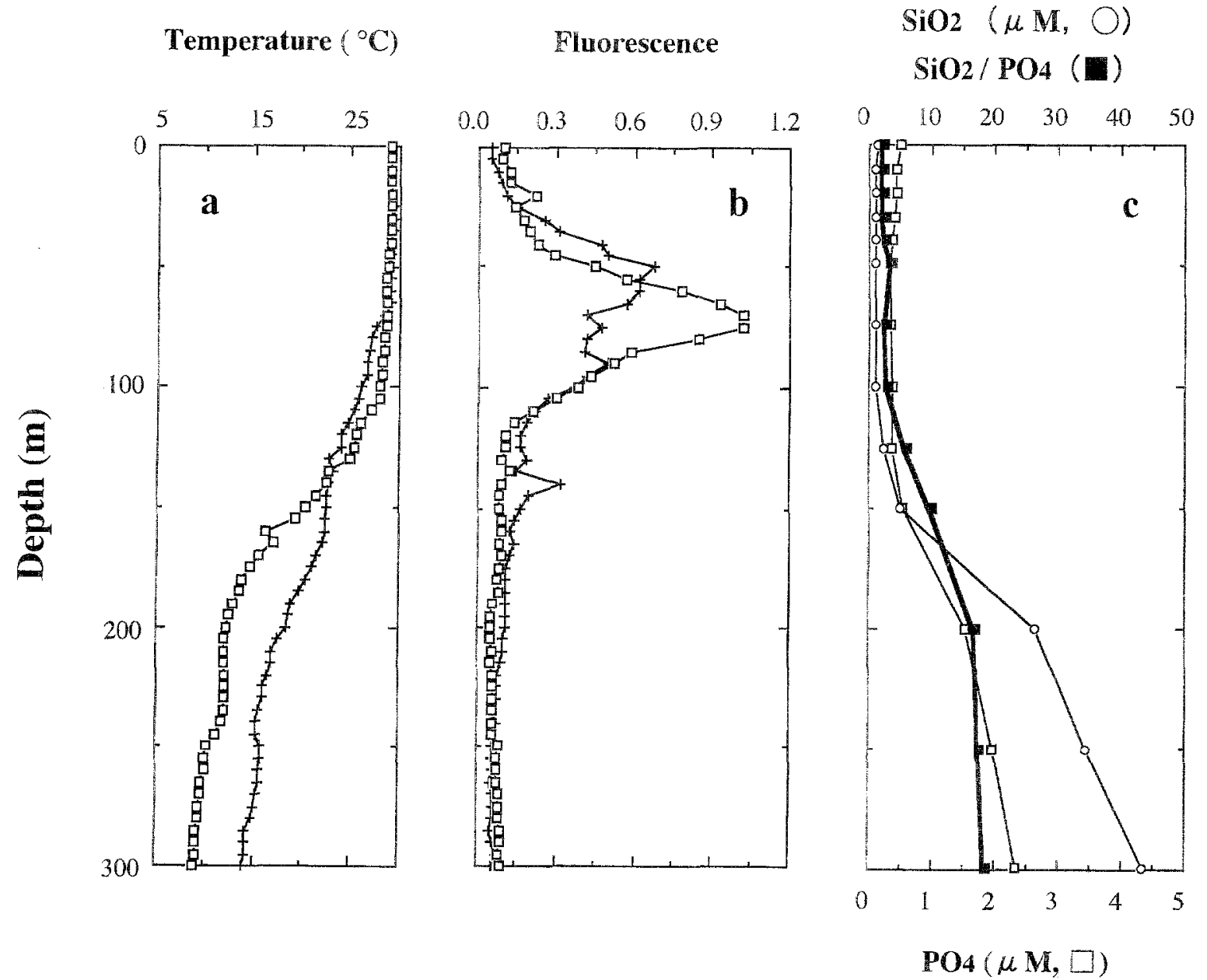

Figure 5. Temperature, fluorescence (indirect indicator for total chlorophyll a), dissolved silica and phosphate concentrations, and dissolved silica/dissolved phosphate ratio versus depth in the surface water at Site 1 during period 1. (+: obtained during May, 199l at Site $1\left(2^{\circ} 59.8^{\prime} \mathrm{N}\right.$, $\left.135^{\circ} 201.5^{\prime} \mathrm{E}\right) . \square, \mathbf{\square}$, obtained during May, 1992 nearby $\left(4^{\circ} 07.5^{\prime} \mathrm{N}, 136^{\circ} 16.6^{\prime} \mathrm{E}\right)$. 
consider the sinking speed of $160 \mathrm{~m} \mathrm{day}^{-1}$, the loss of matcrial during sinking is expected to be small. So we assumed that the sinking flux at the deep trap was not significantly different from the amount reaching the sea floor. The amount of biogenic components collected in the sediment traps and their accumulation in surface sediments at trap sites can be compared for primary productivity values which were taken from the latest productivity map made by Berger et al. [3] (table III). Nitrogen fixation was calculated using the Redfield ratio [26].

Accumulation rates of biogenic components measured in the sediment traps were higher than those of surface sediments at the trap site. The difference was largest for carbonate, which was $99 \%$ less in the surface sediments compared to that in the shallow sediment traps. Carbonate was partly dissolved during vertical transport through the water column, $12 \%$ less in the deep trap compared to that in the shallow trap. This carbonate dissolution is attributed to the reaction of sinking particles with undersaturated deep sea water. The dissolution was accelerated below the lysocline depth of about $3500 \mathrm{~m}$ in the Caroline Basin. The sea floor at $4414 \mathrm{~m}$ at Site 1 was located just above the CCD (Carbonate compensation depth) of about $4500 \mathrm{~m}$. The continuous reaction of settling particles with bottom sea water on the sea floor for long time periods diminished the concentration of carbonate in the surface sediments.

Biogenic opal was about $90 \%$ less in surface sediments compared to that in sediment traps. The ocean at all depths is undersaturated for biogenic opal, but the amount preserved may be proportional to the opal rain rate [4]. Long-term interaction between opal and sea water depleted the opal content. The sedimentation rate is an especially important factor in controlling the burial rate of biogenic opal in surface sediments. Various studies have shown that only a small fraction of the biogenic opal reaching the sediment-water interface is buried in the sediments $[5,24]$.

About $20 \%$ of the organic matter was decomposed between the shallow and deep sediment traps and more than $98 \%$ between the deep sediment trap and final burial in the surface sediments. The relative amount of organic carbon preserved in surface sediments was about $0.10 \%$ of primary productivity. This is in the range of data obtained in the Arabian Sea $(0.10 \%,[8])$ and in the northern North Pacific $(0.008 \%$, [9]). These results confirm that the sediment-water interface is a major site of degradation and dissolution processes of organic matter $[5,12]$. Since the sea floor at Site 1 was below the lysocline, the dissolution of carbonate could have reduced the sealing effect by carbonate, and thus accelerated the degradation rate of organic matter. Nitrogen accumulation rates revealed preservation levels similar to those of organic carbon. The variation of the organic carbon/total nitrogen ratio was not significant at the sediment-water interface. This suggests that inorganic nitrogen which is a byproduct of organic matter during early diagenesis may be fixed into the sediments by replacing alkaline ion sites in the clay minerals and/or by adsorption onto sedimentary particles.

\subsection{The correlation between particle fluxes and wind speed and its implications for paleoceanography}

Climate and hydrography are often reflected in the amount of sinking particle fluxes to the deep ocean [8, 15, 23]. Figure 6 presents sinking particle fluxes at Site 1 as well as wind speed and wind direction versus months in 1991-1992 at Koror, Palau Island ( $\left.7^{\circ} \mathrm{N}, 135^{\circ} \mathrm{E}\right)$, the nearest land-based meteorological station. West wind was stable from June to November and east wind from December to May. High wind speed observed in August-

Table III. Comparison of fluxes of total mass, carbonate carbon, organic carbon, total nitrogen, biogenic opal, and lithogenic matter in primary produced matter with accumulation rates measured in sediment traps and surface sediments.

\begin{tabular}{|c|c|c|c|c|c|c|c|c|c|c|c|c|c|}
\hline & \multicolumn{2}{|c|}{ Total mass flux } & \multicolumn{2}{|c|}{$\begin{array}{c}\text { Carbonate } \\
\text { carbon }\end{array}$} & \multicolumn{2}{|c|}{ Organic carbon } & \multicolumn{2}{|c|}{ Total nitrogen } & \multirow{2}{*}{$\begin{array}{c}\text { Corg/N } \\
\text { molar } \\
\text { ratio }\end{array}$} & \multicolumn{2}{|c|}{ Bingenic opal } & \multicolumn{2}{|c|}{$\begin{array}{l}\text { Iithogenic } \\
\text { matter }\end{array}$} \\
\hline & $\operatorname{gm}^{-2} y^{-1}$ & $\%$ & $\mathrm{gm}^{-2} \mathbf{y}^{-1}$ & $\%$ & $\mathbf{g m}^{-2} \mathbf{y}^{-1}$ & $\%$ & $\mathbf{g m}^{-2} \mathbf{y}^{-1}$ & $\%^{(2)}$ & & $\mathbf{g m}^{-2} \mathbf{y}^{-1}$ & $\%$ & $\mathrm{gm}^{-2} \mathrm{y}^{-1}$ & $\%$ \\
\hline Primary productivity & & & & & 80.0 & & & 100 & & & & & \\
\hline Site 1, Trap (1592m) & 57.10 & 100 & 3.0 & 100 & 3.4 & 4.2 & 0.51 & 3.6 & 7.7 & 14.7 & 100 & 11.4 & 100 \\
\hline Site 1, Trap (3902m) & 53.83 & 94 & 2.7 & $88^{(2)}$ & 2.7 & 3.4 & 0.43 & 3.0 & 7.5 & 14.1 & 96 & 12.7 & 111 \\
\hline Site 1, Sediments $(4402 \mathrm{~m})$ & 9.72 & 17 & 0.0155 & 0.52 & 0.078 & 0.10 & 0.0119 & 0.08 & 7.6 & 1.5 & 10 & 7.9 & 69 \\
\hline
\end{tabular}

(1) Primary production values are taken from Berger et al. [3].

(2) Nitrogen fixation was calculated using the Redfield ratio [26]. 
September and December-February was accompanied with high total mass fluxes at Site 1.

Recent sediment trap experiments in the Arabian Sea showed surface cooling and a deeper mixing of the upper ocean with increasing wind speed [8]. Nutrient input into the euphotic zone associated with this process triggers primary productivity. In addition, the linkage of biogenic activity with a high supply of lithogenic matter increases the efficiency of the organic carbon pump. Another process that stimulates primary production with increasing wind speed is upwelling. Biological study shows that silica-producing planktonic communities live with high nutrient concentration in the centre of upwelling while carbonate-producing communities surround them. The
Corganic/Ccarbonate ratio of sinking particles has been suggested as an indicator of surface ocean fertility with increasing ratios reflecting a more efficient organic carbon pump [1]. The opal/carbonate and Corganic/Ccarbonate ratios of sinking particles showed the surface sea water was more nutrient-rich at Site 1 during periods 2 and 4 than during periods 1 and 3 (figure 6). However, peak fluxes and high carbon rain ratios during period 2 appeared to be delayed with respect to the maximum wind speed. In period 4, flux peaks and wind speed maxima coincided, but higher carbon rain ratios occurred somewhat later towards the end of period 4.

Sea-surface current data provided by the Meteorological Institute of Japan indicate strong eastward currents around
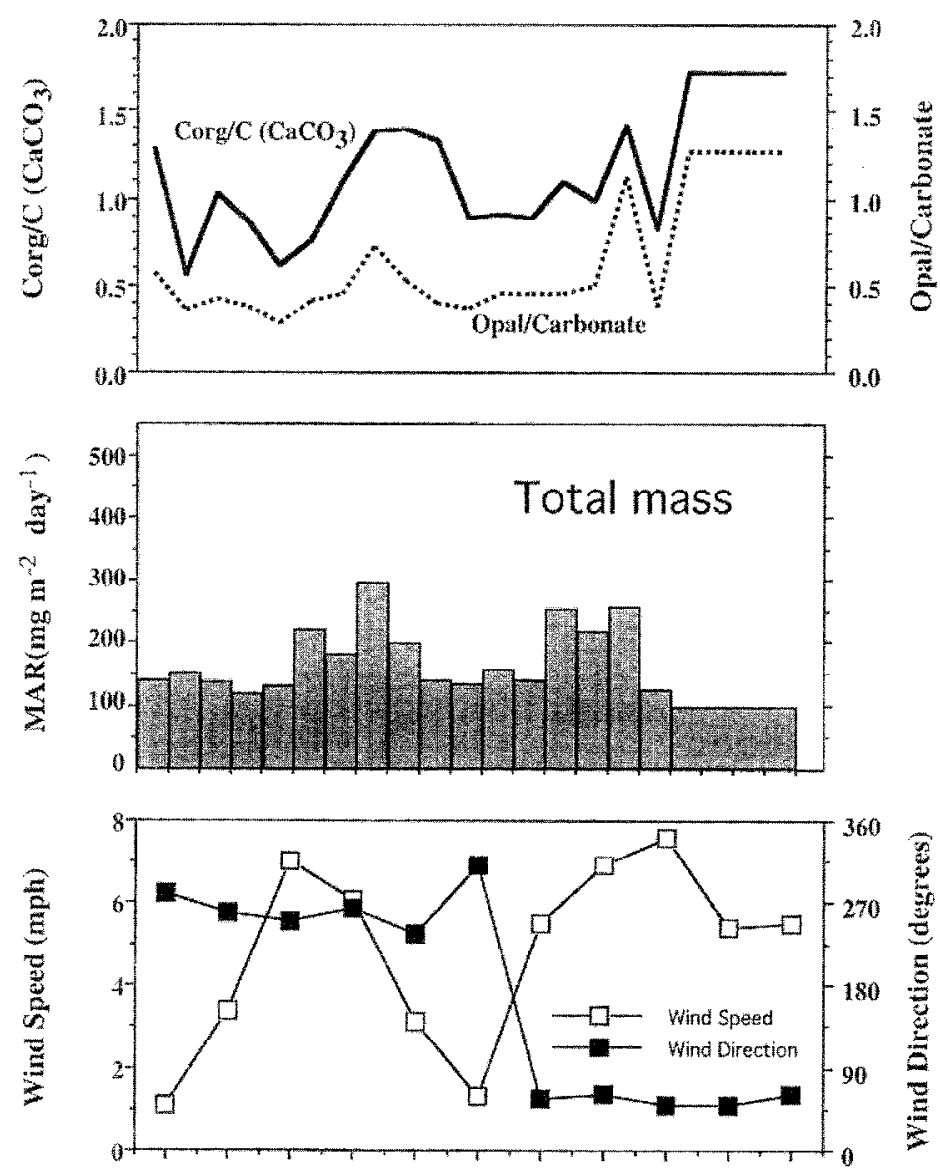

\begin{tabular}{|c|c|c|c|c|c|c|c|c|c|c|}
\hline \multicolumn{2}{|c|}{ Period 1} & \multicolumn{3}{|c|}{ Period 2} & \multicolumn{2}{|c|}{ Period $\$$} & \multicolumn{3}{|c|}{ Period 4} & \multirow[b]{2}{*}{ 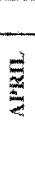 } \\
\hline$\underset{\frac{1}{2}}{\stackrel{2}{2}}$ & $\stackrel{3}{\rightleftarrows}$ & $\begin{array}{l}\frac{5}{3} \\
\vdots \\
3\end{array}$ & $\frac{\frac{c}{2}}{\frac{5}{n}}$ & $\frac{\frac{a}{a}}{\frac{m}{8}}$ & 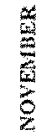 & 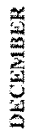 & $\frac{2}{2}$ & 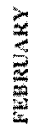 & $\underset{z}{z}$ & \\
\hline
\end{tabular}

Figure 6. Organic carbon/carbonate carbon and opal/carbonate ratios (a) and total flux (b) at the shallow trap of Site 1 and monthly variation of wind speed and wind direction (c) at Koror, Palau Island from June 1991 through May. 
Site 1 , which could supply nutrients from the coastal area off the Philippine and Maluk Islands to the trap site. The water mass should be enriched in land-derived lithogenic matter and its incorporation into fecal pellets or marine snow raises the lithogenic flux. This is supported by the observation of high mass accumulation rate of lithogenic matter at Site 1 during periods 2 and 4. Higher Corganic/ Ccarbonate ratios of sinking particles with higher opal/ carbonate ratio characterised the effective biological pump during these periods (table I and figure 6).

The equatorial upwelling area plays an important role in the discussion about the causes of glacial-interglacial climatic and atmospheric $\mathrm{CO}_{2}$ changes. Much evidence of productivity increase during the last glacial maximum has been gathered for the eastern equatorial Pacific [21, 25]. In the western equatorial Pacific, the accumulation of organic carbon was mainly controlled by primary productivity. Paleoproductivity estimates calculated by using the formula of Sarnthein et al. [27] are considered to be the most reliable, because the fluctuating pattern correlated closely with changes in the accumulation rate of biogenic opal in core sediments taken just at Site 1 [17]. The primary productivity in the West Caroline Basin showed an increase during Stage 8 , Stage $7 / 6$ boundary, late Stage 6, Stage 3, and Stage 2. The results from sediment trap experiments imply that the biological pump is effective with high activities of opal-producing planktonic community, and that during the glacial stages the biological pump was effectively removing carbon from the surface water in the equatorial area of the West Pacific Occan.

\section{SUMMARY AND CONCLUSIONS}

We present time-series data on fluxes of sinking particles from the West Caroline Basin in the equatorial western Pacific. The following points summarise the data interpretation:
1. Annual mass flux at the shallow trap at Site 1 was $57.10 \mathrm{~g} \mathrm{~m}^{-2} \mathrm{yr}^{-1}$. Generally, higher fluxes of organic matter were associated with higher activities of biogenic opal- and carbonate-producing plankton communities. As the organic matter content increases, the organic carbon/ carbonate carbon ratio shows a tendency to increase. Carbonate-producing plankton is predominant during periods 1 and 3 , which could be due to limited silica supply to the euphotic zone.

2. The amount of hiogenic components collected in the sediment traps and their accumulation in surface sediments at Site 1 could be compared in terms of primary productivity values. Carbonate flux was $99 \%$ less in the surface sediments compared to the shallow sediment trap, due to the reaction with undersaturated deep sea water on the sea floor, rather than during sinking through the water column. Biogenic opal was about $90 \%$ less in surface sediments than in the shallow sediment trap. About $20 \%$ of the organic matter was decomposed between the shallow and deep sediment traps, and more than $98 \%$ between the deep trap and final burial in the bottom sediments. The relative amount of organic carbon preserved in surface sediments was about $0.10 \%$ of primary productivity.

3. Based on the opal/carbonate and Corganic/Ccarbonate ratios of sinking particles, surface sea water was more nutrient-rich during periods 2 and 4 at Site 1 . These high total mass fluxes could be stimulated by wind.

\section{Acknowledgments}

The authors express their appreciation to Prof. V. Ittekkot (University of Hamburg), Dr. L.P. Gupta and two reviewers for valuable suggestions to improve the manuscript. This study was supported by the following research programmes; "Northwest Pacific Carbon Cycle study" consigned to the Kansai Environmental Engineering Center Col. Ltd. by the New Energy and Industrial Technology Development Organization.

\section{REFERENCES}

[1] Berger W.H., Keir R., Glacial-Holocene changes in atmospheric $\mathrm{CO}_{2}$ and the deep-sea record, in: Climate Processes and Climate Sensitivity, Hansen J.E. and Takahashi T., (eds) Amer. Geophys. Union Geophys. Monog., Washington, D.C., 29 (1984) 337-351.

[2] Berger W.H., Fischer K., Lai C., Wu G., Ocean productivity and organic carbon flux. I. Overview and maps of primary production and export production, Univ. California, San Diego, SIO Reference (1987) 87-30.
[3] Berger W. H., Fisher K., Lai C., Wu G., Ocean carbon flux: global maps of primary production and export production, in: Biogeochemical Cycling and Fluxes between the Deep Euphotic Zone and Other Oceanic Realms. C. Agegian (ed.) NOAA Natl. Undersea Res. Progr. Res. Rep. 88-1 (1988) 131-176.

[4] Broecker W.S., Peng T.H., in: Tracers in the sea, LamontDoherty Geological Observatory, Columnbia University, New York (1982) $690 \mathrm{p}$. 
[5] Cole, J.J., Honjo S., Erez J., Benthic decomposition of organic matter at a deep-water site in the Panama Basin, Nature 327 (1987) 703-704.

[6] Dymond J., Collier R., Biogenic particle fluxes in the equatorial Pacific: Evidence for both high and low productivity during the 1982-1983 El Nino, Global Biogeochem. Cycles 2 (1988) 129-137

[7] Haake B., Ittekkot V., Die wind-getriebene "biologische Pumpe" und der Kohlenstoffentzug im Ozean, Naturwissenschaften 77 (1990) 75-79.

[8] Haake B., Ittekkot V., Rixen T., Ramaswamy V., Nair R.R., Curry W.B., Seasonality and interannual variability of particle fluxes to the deep Arabian Sea, Deep-Sea Res. 40 (1993) 1323-1344.

[9] Handa, N., Tanoue E., Carbon cycle in the ocean, La Mer 18 (1980) 30-39 (in Japanese).

[10] Honjo S., Coccoliths: production, transportation and sedimentation, Deep-Sea Res. 1 (1976) 65-79.

[11] Honjo S., Seasonality and interaction of biogenic and lithogenic particulate flux at the Panama Basin, Science 218 (1982) 883-884.

[12] Honjo S., Manganini S.J., Cole J.J., Sedimentation of biogenic matter in the deep sea, Deep-Sea Res. 29 (1982) 609-625.

[13) Honjo S., Dymond J., Collier R., Manganini S.J., Export production of particles to the interior of the equatorial Pacific Ocean during the 1992 EqPac experiment, Deep-Sea Res. 42 (1995) 831-870.

[14] Honjo S., Spencer D.W., Gardner W.D., A sediment trap intercomparison experiment in the Panama Basin, 1979, Deep-Sea Res. 39 (1992) 333-358.

[15] Ittekkot V., Particle flux studies in the Indian Ocean, EOS, Transactions, AGU 72 (1991) 527-530.

[16] Ittekkot V., Haake B., Bartsch M., Nair R.R., Ramaswamy V., Organic carbon removal in the sea: The continental connection, in: Evolution of Upwelling Since Early Miocene, W.L. Prell et al., (eds) Geol. Soc. London Publ., Blackwell Scientific (1991) 167-176.

[17] Kawahata H., Suzuki A., The fluctuation of primary productivity during the last $300 \mathrm{kyr}$ in the West Caroline Basin, J. Geol. Soc. Japan 100 (1994) 762-770 (in Japanese with English abstract).

[18] Kawahata H., Ahagon N., Eguchi N., Carbonate preservation variation in the Caroline Basin during the last $330 \mathrm{kyr}$, Gechem. J. 31 (1997) 85-103.

[19] Kempe S., Knaack H., Vertical particle flux in the Western pacific below the North Equatorial Current and the Equatorial
Counter Current, in Particle Flux in the Ocean, (ed.) by V. Ittekkot, Schafer, P, Honjo S., and Depetris P.J., SCOPE, John Wiley and Sons Lid. (1996) 313-323, Toronto, Canada.

[20] Koblentz-Mishke O.I., Volkovinsky V.V., Kobanova Y.G., Plankton primary production of the World Ocean, in: Scientific Exploration of the South Pacific, W. Wooster (ed.) Washington, D.C.: National Academy of Sciences, (1970) $183-193$.

[21] Lyle M., Climatically-forced organic carbon burial in the equatorial Atlantic and Pacific Oceans, Nature 335 (1988) 529-532.

[22] Mortlock R.A., Froelich P.N., A simple method for the rapid determination of biogenic opal in pelagic marine sediments, Deep-Sea Res. 36 (1989) 1415-1426.

[23] Nair R.R., Ittekkot V., Manganini S.J., Ramswamy V., Haake B., Degens E.T., Desail B.N., Honjo S., Increased particle flux to the deep ocean related to monsoons, Nature 338 (1989) 749-751.

[24] Noriki S., Tsunogai S., Particulate fluxes and major components of settling particle from sediment trap experiment in the Pacific Ocean, Deep-Sea Res. 33 (1986) 903-912.

[25] Pedersen T.F., Nielsen B., Pickering M., Timing of late Quaternary productivity pulses in the Panama Basin and implications for atmospheric $\mathrm{CO}_{2}$, Paleoceanography 6 (1991) 57677.

[26] Redfield A.C., Ketchum B.H., Richards F.A., The influence of organisms on the composition of sea water, in: The Sea, Vol. 2. M.N. Hill (ed.) Wiley, New York, 1963, 26-77.

[27] Sarnthein, M., Winn K., Duplessy J.C., Fontugne M.R., Global variations of surface ocean productivity in low and mid latitudes: Influence on $\mathrm{CO}_{2}$ reservoirs of the deep ocean and atmosphere during the last 21,000 years, Paleoceanography 3 (1988) 361-399.

[28] Takahashi K., Seasonal fluxes of pelagic diatoms in the subarctic Pacific, 1982-1983, Deep-Sea Res. 33 (1986) 12251351.

[29] Tchernia P., Descriptive regional oceanography, Pergamon Marine Series, 3, Pergamon Press, Oxford (1980) 253.

[30] Wefer G., Fischer G., Seasonal patterns of vertical particles flux in equatorial and coastal upwelling areas of the eastern Atlantic, Deep-Sea Res. 40 (1993) 1613-1645.

[31] Yamamuro M., Kayanne H., Rapid direct determination of organic carbon and nitrogen in carbonate-bearing sediments using Yanako MT-5 CHN analyser, Limnol. Oceanogr. 40 (1995) 10011005. 